\title{
The Strategy of a Region Development under the Conditions of New Actual Economic
}

\section{Mikhail Yakovlevich Veselovsky}

State Institution of Higher Academic Education of Moscow Region, "Financial Technology Academy"

Russia, 141070, Moscow Region, Korolev, Gagarin Street, 42

\section{Julia Vladimirovna Gnezdova}

Federal State-Funded Educational Institution of Higher Professional Education, «Smolensk State University» Russia, 214000, Smolensk, Prghevalskogo Street, 4

\section{Julia Alexandrovna Romanova}

Federal State-Funded Educational Institution of Higher Professional Education "Financial University under the Government of the Russian Federation", Russia, 125993, Moscow, Leningrad Prospect, 49

\section{Irina Vladimirovna Kirova}

State Institution of Higher Academic Education of Moscow Region, "Financial Technology Academy" Russia, 141070, Moscow Region, Korolev, Gagarin Street, 42

\section{Ibragim Iragiyevich Idilov}

\begin{abstract}
Federal Public Budgetary Educational Institution of Higher Education "Grozny State Oil Technical University of a Name of the Academician M. D. Millionshchikov", Russia, 364051, Chechen Republic, Grozny, Ordzhonikidze Square, 100
\end{abstract}

\section{Doi:10.5901/mjss.2015.v6n5s2p310}

\section{Abstract}

The article studies the region from the social-economic development level point of view, which is a complicated object and could not be assessed by the one of its indices. The article also proves the necessity in a region strategy formation as an important part of a country's social-economic development programme formation. It gives the methodological recommendations for regions' development: the need in continuation of their further economic development on the new qualitative basis because of the Russian economy progress as compared with the world economy; transfer to the post-industrial and information society with special functions for different regions, changes in the way of life and requirements to the development of the social sphere connected with these changes.

Keywords: development strategy, social-economic policy, region.

\section{Introduction}

Development strategy formation in regions becomes the basis of the country well-being in general and mostly depends on the enterprises production capacity. The fundamental mechanism for the formation of regional development management and it's organisation-economic mechanism is the classification of administrative-territorial entities in the Russian Federation according to the level of effectiveness that allows us to define and describe the formation rules and distribution of the innovative technologies in use.

The differences by the regions in the country according to their resource provision proves the necessity in socialeconomic development management within the frameworks of their territorial specialisation and the necessity for their interregional interaction. One of the most prospective ways of solving this issue is the implementation of the widely used differential approach while developing regional strategy in the regions taking into account the possibility of group interaction within different regions. (Mikhailov S.N. and Balyabina A. A., 2008)

The aim of this work is to scientifically prove the theoretic-methodological approach to the region development strategy process of formation, which takes into account possible priorities of the development in accordance to the 
expected dynamics of the gross regional product production and allows to define and describe rules of formation and technologies distribution to provide the economic safety of the country. The actuality of this issue is conditioned by the fact that the study and use of the world experience allows us to bring the regions and the country through the crisis and increase their development taking it to a new higher level. In this sense the experience in the sphere of strategic planning, state regulation, innovative policy and region development will allow us to enrich our science and practice and contribute to the stabilisation of the country's economy while being under the complicated crisis conditions.

\section{Methods}

During the study traditional source of initial data for the functional-structural analysis of the economic processes in the region are materials of the state statistics. They allow to effectively evaluate the current economic situation either based on the retrospective data analysis or based on statistical analysis of data in the current moment. The main condition for the change and development of the social-economic system is a stable growth of national economy, which includes regional economies, growth of their effectiveness based on use of foreign and Russian science and practice achievements as the basic factor. Each region should choose its own way of development based on the factor of production (natural resources, human capital), investments, innovations. (Kaluzhskiy M. L., 2007.)

The basis of the methodological development are the process, system, integrational and functional approaches. Theoretical analysis meant the study of individual peculiarities of the modern social sphere and economy development under the condition of unfavourable environmental factors.

Economic-statistical analysis included the tools of governmental regulative policy necessary for the regional development. Individual facts were analysed, grouped and systematised. There was defined a fact that one of the main functions of the municipal and governmental power is the formation of a social-economic strategy of the region as the basis for territorial competitive advantages formation of the economy in the region and increase in the quality of life. The following theoretical methods for formalisation and generalisation of the results of the investigation were used: method of abstraction, deduction, formalisation and general-logic method. (Mitrofanova I. V., 2006)

Theoretical methods were connected with the study of special literature within the frameworks of forecasting the social-economic processes in the regions development.

The study of literature allowed us to find out known and problematic parts of the strategy in the social-economic development of the region. A lot of attention was paid to the issues being under the scientific discussions, some of them are already well studied but the others are not yet solved.

\section{Results}

\subsection{The investigation of the modern tendencies of Russia's development and development of the regions.}

Nowadays one of the most difficult tasks in the modern Russian economy history is the dynamic development of different types of regions in the general system of economy. The regions differ from each other by different potential of interests and competitive ability of regional development that can be effectively interfered into the whole economy development model of the country in general.

For more than twenty-five years, Russia has been under the condition of crisis. According to the World Bank (WB) data for 2013 Russia takes 9th place in the world economy for the total amount of GDP, and its share in the world gross product is only $2.7 \%$, i.e. much less than in 1917. According to the opinion of WB experts Russia can have such rating for a long time (Deren V. I., 2014).

For these years we have lost almost $2 / 3$ of the industrial potential of the country, we have a constantly growing deindustrialisation of the economy, sale of the national well-being of the country - its natural resources (grain, wood, metals, oil, gas, precious gems, fertilizers).

By 2012 Russia has not reached the development level of 1990 for the majority of the types of agricultural and industrial production. Thus, making a comparative characteristics of the production indices of 2012, Russia had the following indices: coal mined 356, and in 1990 - 395 million tonnes, steel produced - 70.4 and 89.6 million tonnes respectively, grain harvesters -5.8 and 65.7 thousand pieces, computer-controlled machines - 166 and 16741 pieces, timber -21.2 and 75 thousand $\mathrm{m}^{3}$, tractors -13.5 and 214 thousand pieces, tissues of all types -3.9 and 8.4 billion $\mathrm{m}^{2}$, shoes -103 and 385 million pairs. Today the energy resources that are the basic objects of import has reached the level of 1990. In 1990 there was produced 1857 and in 2012 - 1860 million tonnes of reference fuel in Russia; the oil was made in the amount of 513 and 519 million tonnes and gas - in the amount of 641 and 655 billion $\mathrm{m}^{3}$. 
By the 90th of the 20th century Russia took the leading positions in the world for civil aircraft industry and armament. Fleet of civil aviation with the Russian aircrafts took then more than 40\% of the world, and in 2014 their share is less than $7 \%$. According to the vice-prime minister D. Rogozin, the Russian sky has only $7 \%$ of the Russian aircrafts.

Nowadays Russia has lost almost all the sectors of the world market of advanced technology products where it used to take leading positions. In 1989 high value added goods comprised 38.7\% of the USSR's export, but in 2014 it is only $4.7 \%$. High technologies (nuclear equipment, space engineering, armament) comprise only $0.13 \%$ of the Russian export.

The agriculture sector of the Russian economy is also significantly damaged. From 1990 to 2012 the cultivated areas in Russia shortened from 763.0 to 117.7 million ha, application of organic fertilizers - from 389.5 to 54.2 million tonnes, application of mineral fertilizers shortened from 9.9 to 1.9 million tonnes, provision of agricultural enterprises with tractors for every 1000 ha of area from 11 to 4 pieces, grain harvesters - from 7 to 3 pieces, energy capacities - from 419.7 to 102.6 million h.p.

The average annual results of 2006-2010 compared to 1986-1990 were as follows: gross grain harvest shortened from 104.3 to 85.2 million tonnes, the same of the traditional winter ruttishness - from 12.4 to 3.5 million tonnes, flex-fibre - from 124 to 45 thousand tonnes, potato - from 36 to 27.3 million tonnes, fodder corn - from 193.5 to 21.6 million tonnes. From 1990 to 2012 the cattle stock shortened from 57 to 19.9 million pieces including cows - from 20.5 to 8.9 million pieces, pigs - from 38.3 to 13.5 million pieces, production of cattle and bird on carcass weight basis - from 9671 to 6245 thousand tonnes, milk production - from 54.2 to 32.0 million tonnes, butter - from 833 to 216 thousand tonnes, wool - from 225 to 55 thousand tonnes etc. (Deren V.I., 2014).

In order to solve the problem of the qualitative increase of a region's competitive ability according to the authors' opinion it is necessary to form a regional social-economic strategy which would allow to achieve a stable economic growth and reveal the region's potential with the most effective use of the present resources. The necessary condition of the state policy of regional development regulation is the achievement of interest balance for all the participants of the process: inhabitants, state and business in the region while forming and implementing a region's social-economic strategy. (Jensen C., 2008)

\subsection{Key approaches to the formation the criteria and indices of the social-economic development of the region system.}

The development of any region is a multi-criteria and multi-purpose process. The content of the regions development programme always has many differences. There are many opinions for the definition of the concept of "regional development/development of a region". Let us study some of them and define which of the concepts most clearly reflects its sense (Table 1).

Table 1 - Approaches to the definition of a region's development sense.

\begin{tabular}{|l|l|}
\hline Author/source & Definition of "regional development" \\
\hline Kovalenko E. G. & $\begin{array}{l}\text { The regime of a regional system functioning which is oriented to the positive dynamics of the quality and } \\
\text { level of living parameters, it is provided with the balanced and stable reproduction of potentials (resource, } \\
\text { social, ecological, economic potentials) of the territory. }\end{array}$ \\
\hline Gavrilov A. I. & $\begin{array}{l}\text { Multi-dimensional and multi-aspect process that is usually considered from the point of view of the total } \\
\text { sum of the social and economic goals. }\end{array}$ \\
\hline Podprugin M. O. & $\begin{array}{l}\text { Any progressive change in the economic sphere: quantitative (economic growth) or qualitative (structural } \\
\text { changes of the development content) as well as the social parameters of development. }\end{array}$ \\
\hline
\end{tabular}

The development of the region is often considered from the point of view of different economic combination and social goals. In this case, the formation of the social-economic strategy is a single interacting complex of opportunities and abilities of business, authority and society to collect, implement and develop the potential which provides a high level of a region's competitive ability. There is no doubt that certain unification is necessary while developing the strategy due to the fact that the entities of the Federation are the elements of the general social-economic, legislative, social-political state system and the state strategy should be bound to all the entities of the RF with which it interacts in a definite period of time or in the future. (Veselovsky M.Y, Kirova I.V., Reznikova A.V., Rybchicnhuk O.A., 2014)

In order to solve certain tasks of the regional development it is necessary to use the numerous combination of approaches on the modern stage of the Russian social development and economic sphere in general. The best thing is to combine the approaches of technological and innovative approaches, Keynesian approach and balance search 
approach, theory of regulation and institutionalism. (Isard W., 1960). The method and the mechanisms of the above mentioned integrated approaches to the regional development are reflected in the methodological approach to the formation and implementation of the region's social-economic development strategy, which is impossible without the measuring, considering and pointing out regulating factors of regional development state policy. The distinctive feature is the definition of some balanced state of the system based on Guldberg-Vaage ratio where in the residual period while further investigation of the cause-and-effect character of deviations from such state of an object of investigation. (Sampson, G., \& Woolcock, S., 2003)

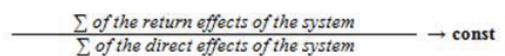

(1)

In this case, the influence of the environment on the system is direct and the responsive inner influence of the system on the environment is reverse. The value of "const" ratio shows that the system will be balanced within the existing boundaries of the outer environment. This method is based on the comparison of quantitative and qualitative indices of the system with the help of aggregate index, for example: (Perry F.,1998)

$$
\mathbf{J}_{\mathbf{p}}=\frac{\sum \text { of the return effects of the system }}{\sum \text { of the direct effects of the system }}: \frac{\sum \text { of the return effects of the system }}{\sum \text { of the direct effects of the system }} \text { (2) }
$$

where Jp is an aggregate index which characterised the correspondence of qualitative indices of the homogeneous systems to the qualitative indices of the outer environment.

As the result of the use of the formula, the following variants of the calculations are possible:

$\mathrm{Jp}=1$ - the system is in balance with the outer environment and has no resources for the further development;

$\mathrm{Jp}<1$ - the system degrades since the comparative effectiveness of its functioning falls behind the indices of the outer environment;

$\mathrm{Jp}>1$ - the system has potential for the further development since the comparative effectiveness of its functioning exceeds the indices of the outer environment.

The aggregate nature of the above-mentioned index allows us to the effectively use it both for the full and partial analysis of the social-economic state on the regional level. Besides this index can be used for the analysis of influence of certain types of expenditures on the adaptiveness of regional economy to the outer conditions. It allows to reveal the correspondences of this system to the outer factors, comparison of numerous systems adaptiveness or for the performing of the internal analysis of certain system elements effectiveness, i.e. almost on all system levels. (Edited M. Ray Ferryman, James R. Schmidt, 1990)

Using this method under the current actual economic for the development of the import substitution programmes in industry, agriculture and other spheres of economy regions of the country can be divided into five groups. The first group is Republics of Bashkortostan, Tatarstan as well as Nizhny Novgorod, Samara, Sverdlovsk region, Chelyabinsk, Belgorod, Vologda and Lipetsk regions. These regions have the most crisis-stable economy with the developed infrastructure, quite diversified industry and highly qualified human resources. These regions will have only a slight economic recession and will retain high demand for the basic sectors products.

The second group consists of the primary regions: Republics of Komi, Sakha (Yakutiya), Khakasiya; Krasnoyarsk; Kemerovo, Magadan, Omsk, Orenburg, Tomsk and Tyumen regions which are characterised by quite high level of production per capita and low recession of production.

The third group has 8 regions of the Central part of Russia: Smolensk, Tula, Ulyanovsk, Vladimir, Ivanovo, Kursk, Moscow and Yaroslavl regions. These regions have high production potential, qualifies human resources and developed infrastructure.

The fourth group comprises of 17 regions of the Russian Federation: Republic of Karelia, Perm territory, Arkhangelsk, Orel, Penza, Ryazan, Sakhalin, Tver, Vologda, Voronezh, Kaluga, Kamchatka, Kostroma, Leningrad region, Murmansk and Novgorod regions. These regions do not refer to the number of the most depressed ones, as well as to the most favourable regions. In order to strengthen the economic potential in the mid-run it is necessary to take measures for supporting general character in the short-term perspective; these measures should be directed to the solving of the problems peculiar for these regions. The same measures should be referred to the three most important agricultural regions: Krasnodar and Stavropol territories and Rostov region.

As for the other regions (the fifth group) due to different reasons (economic, political, geographical) their economic potential is prospective though their growth needs targeted governmental support. (Lyasnikov N.V., Dudin M.N., Sekerin V.D., Veselovsky M.Y., Aleksakhina V.G., 2014) 


\subsection{The principles of formation of new organisational structures for region's development management.}

The basic methodological approach of formation and strategy implementation of the social-economic region development is the organisation-economic mechanism (figure 1) which determines the order and procedure of the government bodies interaction, business and inhabitants, organisation forms within the framework of its implementation as well as the tools and economic methods which define the goals of social and economic development in the region, main development strategy choice, monitoring system and results control within the framework of region's potential and resources effective usage. (Varshavskiy V. R., 2009)

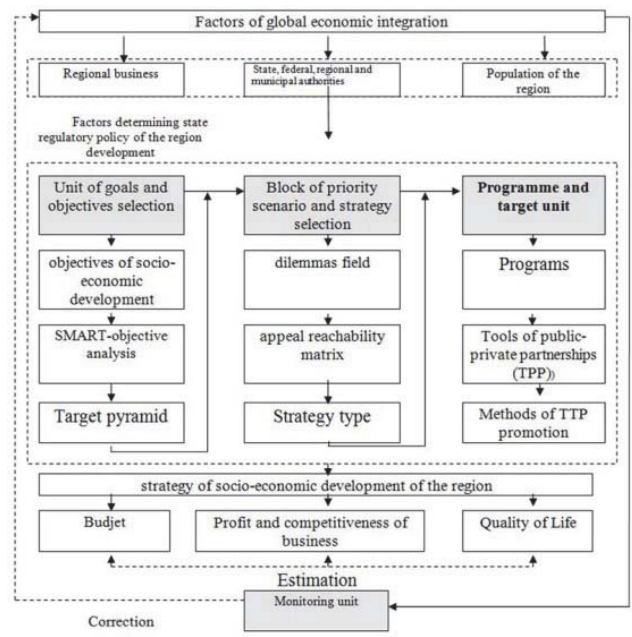

Figure 1 - Organisation-economic mechanism of formation of the strategy of the region's social-economic development

The main chain of the organisation-economic mechanism of strategy formation consists of the four functional modules: module of the selection of a strategy and priority scenario of development, module of goal-setting, module of results monitoring, programme-methodological module. The mechanism of organisation of interrelation of business, people and governmental bodies within the framework of effective regional development provision in relation to the growth of living quality and its competitive ability is shown on figure 2 (Varshavskiy V. R., 2009).

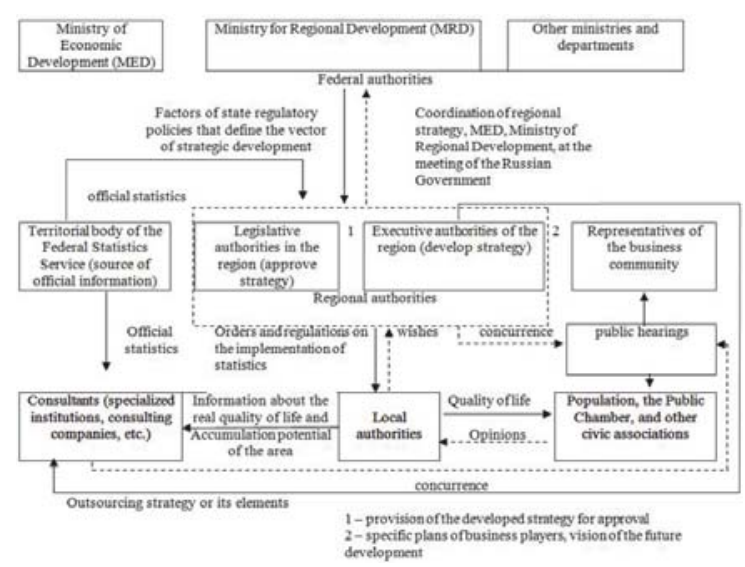

Figure 2 - Mechanism of interaction between governmental bodies, business and people in the process of socialeconomic strategy formation for the region development. 
This method of social-economic strategy formation for the region development allows to increase the quality of the regional planning as the basic function of the governmental power. Organisation-economic mechanism of the socialeconomic strategy formation for the region development takes into account main aspects that appear in the process of development and implementation of the strategy. It allows to offer an effective instrument of the state policy development for regions which is necessary for the qualitative planning process provision and further effective management of the offered measures complex to achieve the region's social and economic development priorities. (Khasaev G. R., Tsybatov V. A., 2007)

\subsection{The priorities of a region's development within the framework of the country's economic safety formation.}

During the period of instability on the world market there is still a possibility of the regions progressive development in the RF. During the past years, a lot of attention was paid to the country's economic safety provision, especially under the conditions of economic globalisation. The concept of "regional safety" is the basic category of "national safety", which provides the possibilities for the subjects of the federation that help solving internal problems, while customising to the changing conditions of the outer environment. (Alekhnovich S. O., 2007)

Regional safety is included into the system of national safety, being an independent sub-system, which is characterised by the definite state of security for the vital interests in the Russian Federation regions. The more stable the regions are the higher is the level of national security interests for the Russian Federation from the outer and inner threats. Basic vital national and regional safety indices are the same. (Concept of the development of the RF up to 2020)

In October 2014 academician Glaziev S. Yu. in his report "About the outer and inner threats of the economic safety of Russia under the conditions of American aggression" (Glaziev S. Yu. 2014) held in the Russian Academy of Science showed 60 indices which characterised the reproduction of economic potential, reproduction of human potential, external economic dependence of Russia and competitive ability of its economy in 2013.

According to Glaziev S. Yu. one can use only one of the 60 indices (international reserves sufficiency coefficient expressed in percent to the volume of import of goods and services for three months) to see that actual state is 4.4 times better than extremely critical one; according to 10 indices (GDB per capita, inflation rate, trade balance deficit, population aging factor, ratio of cash income per capita and level of the cost of living, index of human potential development etc.). Actual state is within the normal values; according to other 49 indices the actual state is worse than extremely critical state, including the 23 indices according to which the actual state is two or more times worse than the extremely critical one (Glaziev S. Yu., 2014). Using the tables by S. Yu. Glaziev let us show only some of the indices (Table 2).

Table 2 - Comparison of actual indicators of economic safety and threshold values of economic safety in Russia in 2013

\begin{tabular}{|c|c|c|c|}
\hline Indicators & $\begin{array}{l}\text { Actual index to the } \\
\text { extremely critical }\end{array}$ & $\begin{array}{c}\text { Extremely } \\
\text { critical value }\end{array}$ & $\begin{array}{l}\text { Actual } \\
\text { state }\end{array}$ \\
\hline GDP to the world amount (\%) & 2.7 times worse & 7.5 & 2.5 \\
\hline Natural population growth (a person per 1000 of inhabitants) & 62 times worse & 12.5 & 0.2 \\
\hline Depreciation of fixed assets (\%) & 1.95 times worse & 40 & 78 \\
\hline Share of engineering in industry (\%) & 1.79 times worse & 25 & 14 \\
\hline Amount of the total foreign debt (\% to GDP for the end of the year) & 1.4 times worse & 25 & 34.8 \\
\hline Share of imported equipment in the home demand (\%) & 2.18 times worse & 30 & 65.6 \\
\hline $\begin{array}{l}\text { Disparity between incomes 10\% of the most secured and } 10 \% \text { of the most unsecured } \\
\text { groups (in times) }\end{array}$ & 2 times worse & 8 & 16.2 \\
\hline Share of people with the incomes lower than the level of the cost of living (\%) & 1.6 times worse & 7 & 11 \\
\hline Unemployment rate & 1.1 times worse & 5 & 5.5 \\
\hline Amount of capital investments (\% to GDP) & 1.25 times worse & 25 & 19.8 \\
\hline Share of products of manufacturing industry in export (\%) & 2.17 times worse & 50 & 23 \\
\hline Share of new types of products in the general amount of engineering products (\%) & 3.7 times worse & 7 & 2.6 \\
\hline Expenditures for the scientific investigations (\% to GDP) & 2 times worse & 3 & 1.5 \\
\hline Share of imported foodstuff in GDP (\%) & 1.07-1.28 times worse & $25-30$ & 32 \\
\hline Share of export in material production (\%) & 3.76 times worse & 25 & 94 \\
\hline Amount of foreign currency in relation to rouble mass in national currency (\%) & 5 times worse & 10 & 50 \\
\hline Volume of foreign trade turnover ratio (\% to GDP) & 3.5 times worse & 30 & 107 \\
\hline Share of innovation-active enterprises (\%) & 4 times worse & 40 & 10.1 \\
\hline Average annual rate of growth of labor production (\%) & 2 times worse & 6 & 3 \\
\hline Relative share of the Russian high-tech products on the world market (\%) & 10 times worse & 3 & 0.3 \\
\hline Share of intellectual property in the cost of business (\%) & 2.5 times worse & 25 & 10 \\
\hline
\end{tabular}


Nowadays economic safety of Russia still suffers significant, growing inner and external threats. This was especially noticeable in 2014 under the conditions of imposing sanctions towards Russia. One of the basic problems of safety provision for both the Federation in general and its regions, is the interrelations of the federal centre and its subjects in the issues of economic sphere. Economic space of the country is characterised by certain differences in social and economic development of its regions. A number of reasons the main ones are as follows: Russia's possession of the lands with differentiated structure of economy and mind-set of people and authority (the so-called regional definition or regional self-cognition); maximum latitude of the state regulating role, actual economic and legal inequality of the subjects. The model of regional safety management defines differences in social and economic development in the regions, in particular on the state-based level, which forms conditions that allow to response to the external challenges and threats. While performing the comparative analysis of Russian economic and social development indices depending on the region the existence of the economically struggling regions in Russia is proved by many investigations, made by independent Russian social structures. The regions of Far East, Siberia and South are the most challenged (Idilov I.I., 2014).

Today the legal economy of Russian regions is provided with all the necessary political and legal conditions for the regional safety policy formation. Despite the differences in the rates of social life and economy reforming there is always a system of democratic and market institutions in regions which define a single political and legal space. In the process of defining the regional safety priority directions one should take into account a real state of regional economy, of legitimate social level and population economic practices, social infrastructure, effectiveness of regional authority institutions. (Suvorov A. V., Gorst M. Yu., 2008)

\section{Discussion}

The current study of the formation strategy in region development under the conditions of new actual economic is based upon the methods of practical and theoretic cognition. As the result of communication, analysis, economic and statistical information systematisation on regional economic development we managed to prove the hypothesis of the necessity in the region development strategy formation. This strategy would take into account possible priorities of development according to the forecasting dynamics of the gross regional product and tools production, which describes the rules of technologies formation and distribution to prove economic safety in the region and the country in general. High authenticity of the results is based on the studies of the following authors: Deren V. I., Aganbegyan A. G., Bandman M. K., Granberg A. G., Egorov V.V. etc. The distinctive feature of this investigation is the attempt to take into account the specific nature of the Russian regions while forming the strategy of their development with the account to the country economic safety being under the conditions of the growing internal and external threats. While performing the theoretical analysis we revealed and studied the peculiarities of strategy formation in a region development, which is a multiple changes of the state under the condition of preserving positive tendencies in the growth. The paper studies the region from the point of view of social-economic development, which is a complicated object that could not be assessed by the state of one of its indices only. This occurs due to the combination of regional sub-systems: industry, transport, agriculture, service, education, healthcare, economic safety etc. are nominally combined in region. We made a conclusion that the region as an economic unit is basically more mobile and flexible when compared with the whole country, this is the most important competitive advantage under the conditions of indefiniteness of the global competitive environment. (C. Small Brain, 1997). The authenticity of the results is proved by the official statistical data, which can be found on the web site of the Office for National Statistics.

\section{Report}

Thus, the above-described understanding of the regional development differs from the processes of mechanical growth or structural complications. For example, it is impossible to refer the unilateral building of the territory (reclaiming of the Russian North) with industrial objects to the genuine regional development. That is why the quality of the formed strategy of region development depends on the accounting of the interests of the state, business and inhabitants as the basic elements of the regional social and economic system. Such an approach allows to increase the quality of the regional strategies on the stage of development for the account of the works complex combination for the territory development planning in general. Nowadays there is no general organisation-economic mechanism for strategy formation, which could contain all the means and methods for development of regional development strategy complex. That is why the position of the regional economy system in the state russian economy should be defined by a number of indices: natural resources, way of distribution; space localization; financial sufficiency of territory; functional orientation of the main types 
of industry; territory's investment attractiveness; social and economic infrastructure provision; income level and income level differentiation. While proving the effectiveness of regional development social-economic policy strategy it is necessary to take into account some unbiased circumstances such as basic indices functionality in a regional system evolution process; need for sufficient level of competitive ability for the given system; need for basic indices coordination of development in region's real and financial sectors; maximum real threats to the stable region development.

\section{References}

Alekhnovich, S. O. (2007). Federation relations and safety of regional development. Law and policy,4, 43-54.

Varshavskiy, V. R. (2009). Mechanism of formation of a regional social-economic development strategy (according to the materials of Krasnodar Territory). PhD thesis.

Glaziev, S. Yu. (2014). About the outer and inner threats of the economic safety of Russia under the conditions of American aggression: report for the Russian Academy of Science. From http://www.russiapost.su/archives/36344.

Deren, V. I. (2014). Factors that retard the development of the Russian Federation. Applied economic investigations, 1, 83-92.

Mikhailov, S. N. \& Balyabina, A. A. (2008). Regional energetic clusters: problems and prospects. Russian business, 10(120), 20-25. From http://www.creativeconomy.ru/articles/4863/

Kaluzhskiy, M. L. (2007). New approach to the development of method of analysis of regional economic processes. Competitive ability of regional economy: experience, problems and prospects: Materials of the International scientific and practical conference. Messenger of the branch of VZFEl in Omsk, 8, 57-59.

Concepts of long-term social-economic development of the Russian Federation for the period up to 2020, approved by the Government of the RF of 17.11.2008 \#1662-p, from http://www.garant.ru/products/ipo/prime/doc/94365/

Mitrofanova, I. V. (2006). Programme-targeted management of the social-economic development of the region. Social and humanitarian knowledge, 2, 36-50.

Suvorov A. V. \& Gorst M. Yu. (2008). The system of macro-economic balances for the region's economy forecasting. Problems of forecasting, 4, 23-36.

Khasaev, G. R. \& Tsybatov, V. A. (2007). Technology of regional development forecasting: the experience of development and use. Problems of forecasting, 2, 56-69.

Veselovsky, M.Y., Kirova, I.V., Reznikova, A.V. \& Rybchicnhuk O.A. (2014). Main lines of innovative management in the Moscow Region. Life Science Journal, 11(12), 252-254.

Lyasnikov, N.V., Dudin, M.N., Sekerin, V.D., Veselovsky, M.Y. \& Aleksakhina, V.G. (2014). The national innovation system: the conditions of its making and factors in its development. Life Science Journal, 11(8), 535-538.

Idilov, I.I. (2014). New Stage in a Development of Civilization. The gth Road Mayors Forum and the Silk Road Economic Belt Cities Cooperation and Development Forum 2014. Urumgi, WCO.

Isard, W. (1960). Methods of regional analysis. Cambridge: MIT Press.

Trebilcock, M.J. \& Howse, R. (2000). The Regulation of International Trade (2nd Edition), Routledge, London.

Brain, C.S. (1997). The Theory of Pole Growth. The Annals-Regional Science, 1.

Perry, F. (1998). Diffusion of Innovation and Regional Economic Growth. The Annals-Regional Science, 5.

Sampson, G., \& Woolcock, S. (2003). Regionalism, Multilateralism, and Economic Integration: The Recent Experience, UN University Press, Paris.

Ferryman, M.R. \& Schmidt, J.R. (1990). Regional Econometric Modeling. Boston.

Jensen, C. (2008). Creating subregions within the region. The region of Vastra Gotaland seeks its Stability, from http://www.regionalstudies-assoc.ac.ukleventslabstract.htm. 